\title{
A malignus daganatok és az ischaemiás stroke kapcsolata
}

\author{
II. A diagnózisok időrendje és a stroke kezelése
}

\author{
Hajnóczky Nóra dr. ${ }^{1,3}$ - Bereczki Dániel dr. ${ }^{1,2}$ \\ ${ }^{1}$ Semmelweis Egyetem, Általános Orostudományi Kar, Neurológiai Klinika, Budapest \\ ${ }^{2}$ MTA-SE Neuroepidemiológiai Kutatócsoport - Eötvös Loránd Kutatási Hálózat, Budapest \\ ${ }^{3}$ Sidney Kimmel Medical College at Thomas Jefferson University, Philadelphia, PA, USA
}

\begin{abstract}
A malignus daganatok és a stroke együttesen gyakran fordulnak elő a stroke tradicionális rizikófaktoraival (magas vérnyomás, hyperlipidaemia, cukorbetegség, elhízás, dohányzás) rendelkező betegekben. Az elmúlt évtized kutatási eredményei alátámasztották, hogy a rosszindulatú daganatban szenvedő betegekben szignifikánsan nagyobb a stroke kockázata. A malignus daganatokhoz társuló stroke a leggyakrabban a malignus daganat diagnózisát követő fél-egy év során jelentkezik. A kapcsolat a másik irányban is létezik: stroke-betegek követése során malignus daganat szignifikánsan gyakrabban jelent meg, mint a stroke-mentes kontrollcsoportban. A daganatot a leginkább a stroke utáni első hat hónapban diagnosztizálják. A korábban nem ismert rosszindulatú daganat időnként az akut stroke kezelése során derül ki. Ismeretlen eredetú stroke (cryptogen stroke) hátterében rosszindulatú tumorhoz társuló hiperkoagulabilitás is feltételezhető. A háttérben a leggyakrabban tüdőrák áll, ezt az emlőcarcinoma és a melanoma követi. Jelenleg nincs ajánlás a felismert malignus daganatok esetében a stroke primer prevenciójára. A malignus tumor mellett jelentkező akut ischaemiás stroke kezelésére a rekombináns szöveti plazminogénaktivátorral történő intravénás thrombolysis alkalmazható a várható túlélés és a vérzésveszély mérlegelésével; a mechanikus thrombectomia alkalmazásáról kevés az adat, irányelvszintű ajánlások még nincsenek. A másodlagos stroke-prevencióra a kis molekulasúlyú heparinnal történő antikoagulálást javasolják. Jelenleg még nem ismerjük pontos részleteiben a daganat által okozott hiperkoaguláció mechanizmusát, ezért még nem ismert, hogy mi a legjobb módszer tumoros betegeknél a stroke megelőzésére. Nincsenek jól definiált ajánlások arra sem, hogy milyen esetekben lenne indokolt tumorkeresés cryptogen stroke-os betegekben.
\end{abstract}

Orv Hetil. 2022; 163(2): 43-51.

Kulcsszavak: tumorokhoz társuló stroke, patomechanizmus, daganat által okozott hiperkoaguláció, tumorokhoz társuló thrombosis, cryptogen stroke

\section{The relationship between malignant tumors and ischemic stroke}

\section{Chronology of diagnoses and treatment of strokes}

Cancer and stroke occur in similar patient populations, and they have similar traditional risk factors (hypertension, hyperlipidemia, obesity, diabetes, and smoking), therefore, it is beneficial to study the relationship between cancer and stroke. Patients diagnosed with cancer have an increased incidence of acute ischemic cerebral events within the first 6 months up to a year post diagnosis. The reverse relationship is also true for patients diagnosed with stroke and then cancer. Interestingly, patients may have a stroke as their first indication to an underlying developing cancer and will most often be diagnosed with cancer sometime within six months to a year after the cerebral incident. When cancer is diagnosed immediately after a cryptogenic stroke (unknown etiology), the stroke may be a result of cancerassociated hypercoagulability. The most common malignancies observed in the cancer-stroke patients are lung, breast and melanoma. Currently, there are no pharmacologic recommendations for primary stroke prevention in cancer patients. For acute ischemic stroke, life expectancy and the potential for hemorrhagic complications should be considered when deciding on thrombolytic treatment. Only a few case series have been reported on mechanical thrombectomy in malignancies, and there are no guideline recommendations yet. Secondary prevention is advised through low molecular weight heparin. Understanding cancer-associated hypercoagulability and the ways we can prevent the combined effects of cancer and stroke is a crucial gap that requires further studies. Additionally, guides to aid in the recognition of underlying malignancy in patients suffering from cryptogenic stroke need to be established. 
Keywords: cancer-related stroke, pathomechanism, cancer-associated hypercoagulability, cancer-associated thrombosis, cryptogenic stroke

Hajnóczky N, Bereczki D. [The relationship between malignant tumors and ischemic stroke. II. Chronology of diagnoses and treatment of strokes]. Orv Hetil. 2022; 163(2): 43-51.

(Beérkezett: 2021. június 9.; elfogadva: 2021. augusztus 11.)

\begin{abstract}
Rövidítések
$\mathrm{ADP}=($ adenosine diphosphate $)$ adenozin-difoszfát; AHA/ ASA $=($ American Heart Association/American Stroke Association) Amerikai Szívgyógyász Szövetség/Amerikai Stroke Egyesület; $\mathrm{CI}=($ confidence interval $)$ megbízhatósági tartomány; $\mathrm{CT}=$ (computed tomography) komputertomográfia; DOAC $=$ (direct oral anticoagulant) direkt oralis véralvadásgátló készítmény; ESUS = (embolic stroke of undetermined source $)$ ismeretlen eredetű emboliás stroke; $\mathrm{INR}=$ (international normalized ratio) nemzetközi normalizált ráta; IV = intravénás; IVT = intravénás trombolysis; $\mathrm{LMWH}=$ (low-molecular-weight heparin $)$ kis molekulasúlyú heparin; MRI = (magnetic resonance imaging) mágnesesrezonancia-képalkotás; mRS = módosított Rankinskála; NET $=($ neutrophil extracellular traps $)$ neutrophil extracelluláris csapdák; NIHSS $=$ (National Institutes of Health Stroke Scale) az USA Nemzeti Egészségügyi Intézetének stroke-pontozóskálája; $\mathrm{OR}=($ odds ratio) esélyhányados; $\mathrm{tPA}=$ (tissue-type plasminogen activator) szöveti típusú plazminogénaktivátor; $\mathrm{VKA}=\mathrm{K}$-vitamin-antagonista; VTE = vénás thromboembolia
\end{abstract}

A rosszindulatú daganat és a stroke gyakran társulnak. Az együttes előfordulás hátterében állhatnak a hasonló tradicionális rizikófaktorok, de felelős lehet a daganat által okozott hiperkoaguláció és a daganat kezelése (kemoterápia és sugárterápia) is. A daganatos betegben megjelenő stroke pontos oka sokszor nem egyértelmú. Ha a stroke hátterében a daganat által okozott hiperkoaguláció áll, gyakran magasabb a szérum-D-dimer-szint, és a CT/ MR-vizsgálat több érterületben megjelenő ischaemiás károsodást igazol. Összefoglalónk első részében kitértünk a malignus daganatok által okozott thrombosis patofiziológiájára és a tumorok és a stroke átfedő rizikófaktoraira [1]. A jelen áttekintésben vizsgáljuk (1) a stroke és a malignus tumor diagnózisának időbeli jellemzőit, (2) a malignus tumor mellett jelentkező stroke akut kezelésének és prevenciójának lehetőségeit, és (3) kitérünk a cryptogen stroke-ok esetén indokolt tumorkeresésre.

\section{Stroke jelentkezése malignus tumorok diagnózisa után}

\section{A stroke gyakorisága, idöbeli kapcsolata a különbözö tipusú malignus tumorokkal}

Svéd populációban az 1987 és 2009 közötti évekre vonatkozóan azt találták, hogy az újonnan diagnosztizált malignus betegség felismerését követő első 6 hónapon belül a vérzéses stroke kockázata 2,2-szeres (95\%, CI: 2-2,3), míg az ischaemiás stroke kockázata 1,6-szeres (95\% CI: 1,5-1,6) a normálpopulációhoz képest [2]. A diagnózist követő 10 évben is nagyobb volt a stroke kockázata (vérzéses: 1,2, CI: 1,1-1,3, ischaemiás: 1,1, CI: 1,1-1,2) [2]. A malignus daganat felismerését követő első 6 hónapban jelentkező ischaemiás stroke-ok hátterében a leggyakoribb (kétszeresnél nagyobb kockázattal járó) daganatok a vékonybél, a hasnyálmirigy, a tüdő, a központi idegrendszer, az endokrin rendszer daganatai és a leukaemia voltak, míg a vérzéses stroke-ok esetében a vékonybél, a máj, a vese, a központi idegrendszer, a pajzsmirigy, a többi endokrin rendszer daganatai, a kötőszöveti daganatok, non-Hodgkin-lymphoma, myeloma és a leukaemia mellett volt a kockázat kétszeres vagy nagyobb [2].

Egy nagy betegszámú kutatásban az amerikai Medicare-rendszer fekvő- és járóbetegeiben elemezték, hogy az újonnan diagnosztizált első daganatos betegekben milyen gyakorisággal és mikor jelentkezett artériás embolisatio (szívinfarktus és ischaemiás stroke) [3]. A 279719 daganatos beteget elemző vizsgálatban artériás embolisatio a daganatos betegek 4,7\%-ában (95\% CI: 4,6-4,8) jelent meg az első 6 hónapban, miközben a daganatmentes kontrollcsoportban ez az érték 2,2\% (95\%, CI: 2,1-2,2) volt [3]. Szívinfarktus a daganatos betegek 2\%-ában (CI: 1,9-2,0), míg a kontrollcsoport 0,7\%-ában (CI: 0,6-0,7) alakult ki, és ischaemiás stroke a daganatos betegek 3\%-ában (CI: 2,9-3,1), míg a kontrollcsoportnak csak az 1,6\%-ában (CI: 1,6-1,7) jelent meg [3]. Mindegyik primer daganattípusban és a kontrollcsoportban is emelkedett az ischaemiás stroke előfordulása a követési idő növekedésével. Stroke-ok a következő gyakorisági sorrendben jelentek meg primer tumorok mellett a tumor felismerését követő 6. hónapnál: tüdő (5,6\%, 95\% CI: 5,4-5,7), hasnyálmirigy $(3,8 \%, 95 \% \mathrm{CI}: 3,5-4,2)$, gyomor $(3,7 \%, 95 \% \mathrm{CI}: 3,3-4,2)$, colorectalis, nonHodgkin-lymphoma, hólyag, mell, prosztata [3]. A vizsgálatban azt találták, hogy a daganat felismerését követő első év végére az ischaemiás stroke kockázata mindegyik daganattípusban csökkent [3]. A malignus daganatok utáni stroke jelentkezési idejére vonatkozó legnagyobb követéses vizsgálatokat az 1 . táblázatban foglaljuk össze $[2,3]$. 
1. táblázat |A malignus daganat felismerése utáni stroke jelentkezési idejére irányuló nagy, követéses vizsgálatok [2,3]

\begin{tabular}{|c|c|c|c|c|c|}
\hline $\begin{array}{l}\text { Szerző } \\
\text { és évszám }\end{array}$ & Vizsgálati csoport & Kontrollcsoport & $\begin{array}{l}\text { A vizsgált periódus } \\
\text { a daganat után }\end{array}$ & A stroke relatív kockázata $(95 \% \mathrm{CI})$ & Megjegyzés \\
\hline $\begin{array}{l}\text { Zöller, } \\
2012 \text { [2] }\end{array}$ & $\begin{array}{l}\text { Új daganat } \\
\text { diagnózisa a teljes } \\
\text { svéd lakosságban } \\
1987 \text { és } 2008 \\
\text { között; } \\
\text { n = } 820491\end{array}$ & $\begin{array}{l}\text { A teljes svéd } \\
\text { daganatmentes } \\
\text { lakosság }\end{array}$ & $\begin{array}{l}\text { (A) Első } 6 \text { hónap } \\
\text { (B) Fél éven túl }\end{array}$ & $\begin{array}{l}\text { (A) Elsó } 6 \text { hónapban } \\
\text { Ischaemiás stroke: } 1,6(1,5-1,6) \\
\text { vérzéses stroke: } 2,2(2,0-2,3) \\
\text { (B) Fél éven túl } \\
\text { Ischaemiás stroke: } 1,1(1,1-1,2) \\
\text { vérzéses stroke: } 1,2(1,1-1,3)\end{array}$ & $\begin{array}{l}\text { A kockázat az első } 6 \text { hónapban } \\
\text { több mint kétszeres: } \\
\text { Ischaemiás stroke-ra: } \\
\text { a vékonybél, a hasnyálmirigy, a } \\
\text { tüdő, a központi idegrendszer, } \\
\text { az endokrin rendszer daganatai } \\
\text { és a leukaemia } \\
\text { Vérzéses stroke-ra: } \\
\text { a vékonybél, a máj, a vese, } \\
\text { a központi idegrendszer, } \\
\text { a pajzsmirigy, a többi endokrin } \\
\text { rendszer daganatai, a kötőszöveti } \\
\text { daganatok, a non-Hodgkin- } \\
\text { lymphoma, a myeloma és a } \\
\text { leukaemia }\end{array}$ \\
\hline $\begin{array}{l}\text { Navi, } \\
2017 \text { [3] }\end{array}$ & $\begin{array}{l}\text { Új daganat } \\
\text { diagnózisa } 66 \text { év } \\
\text { fölöttiekben az } \\
\text { amerikai Medicare- } \\
\text { rendszerben } 2002 \\
\text { és } 2011 \text { között; } \\
\mathrm{n}=279719\end{array}$ & $\begin{array}{l}\text { Azonos számú, } \\
\text { betegenként } \\
\text { illesztett } \\
\text { daganatmentes } \\
\text { személyek }\end{array}$ & 2 év & $\begin{array}{l}\text { Az ischaemiás stroke kockázata } \\
\text { a daganat felismerése után: } \\
\text { - az első hónapban: 4,5 }(4,1-4,8) \\
\text { - } 1-3 \text { hónap között: } 1,7(1,6-1,8) \\
\text { - 3-6 hónap között: } 1,3(1,2-1,3) \\
\text { - az elsó } 6 \text { hónapban: } 1,9(1,8-2,0) \\
\text { - 6-9 hónap között: } 1,0(1,0-1,1) \\
\text { - 9-12 hónap között: } 1,1(1,0-1,2)\end{array}$ & $\begin{array}{l}\text { Vizsgált daganattípusok: emlő, } \\
\text { tüdő, prosztata, colorectalis, } \\
\text { húgyhólyag, pancreas, gyomor, } \\
\text { non-Hodgkin-lymphoma }\end{array}$ \\
\hline
\end{tabular}

CI = 95\%-os megbízhatósági tartomány

\section{Malignus daganatok jelentkezése a stroke diagnózisa után}

\section{A malignus daganatok gyakorisága, típusa és időbeli jellegzetességei a stroke után}

A stroke-beteg kórházba kerülése alkalmával a vizsgálatok folyamán kiderülhet előzőleg még nem diagnosztizált malignus daganat [4]. Egy 48 hónapon át végzett vizsgálatban 631, akut stroke-os beteg között 2,1\%-ban találtak okkult daganatot, amely a stroke miatti fizikális, laboratóriumi és képalkotó vizsgálatok során derült ki [5]. Az arány még magasabb - 5,3\% - volt idiopathiás stroke esetén [5].

Németországban háziorvosi praxisokban 2006 és 2015 között, a stroke-ot követő 10 évben, 9579 férfiban és 9089 nőben vizsgálták a daganatok megjelenését azonos esetszámú, korban, nemben és 16 társuló betegségben illesztett, stroke-mentes kontrollcsoporthoz hasonlítva. Egy évvel a stroke után nem volt szignifikáns különbség a daganat megjelenése terén a vizsgálati csoportok között sem a férfiak $(3,1$ vs. $2,6 \%, \mathrm{p}=0,273)$, sem a nők $(2,6$ vs. $2,1 \%, \mathrm{p}=0,092)$ körében [6]. A 10 éves követés során stroke után a férfiak 29,3\%-ában alakult ki daganat, míg a stroke nélküli kontrollcsoportban csak $23,8 \%$-ban $(\mathrm{p}<0,001)$ [6]. Malignus daganat nőkben is hasonlóan gyakrabban alakult ki stroke után: 25,0\%-ban, a kontrollcsoport 20,5\%-os értékével szemben $(\mathrm{p}<0,001)$ [6]. Szignifikáns társulást férfiakban a stroke, valamint az emésztőrendszeri, a légzőrendszeri és az intrathoracalis daganatok esetében találtak, míg nőkben a légzőszervi és az intrathoracalis daganatok esetén [6].

A leggyakoribb primer agydaganatok a felnőtt populációban a meningeomák, a glioblastomák és az astrocytomák. Primer agydaganatokhoz társulva is leírtak ischaemiás stroke-ot. Primer agydaganatok mellett jelentkező 68 ischaemiás stroke esetében a háttérben álló tumorok között gliomák (60\%), meningeomák (25\%) és központi idegrendszeri lymphomák (6\%) fordultak elő [7], gyakran mútéti szövődményként. A 68 ischaemiás strokeesetből 29-ben (43\%) a stroke után, a stroke miatti vizsgálatok során ismerték fel a daganatot [7].

A bergeni NORSTROKE-vizsgálatban 1282, daganatmentes ischaemiás stroke-beteg több mint 2 éves követése során 55 -nél $(4,3 \%)$ jelentkezett malignus tumor; a stroke és a daganat diagnózisa közötti medián időtartam 14 hónap volt, és a tüdőrák volt a leggyakoribb [8]. Az 55 betegből 23 betegnél (42\%) l éven belül, 13 betegnél $(24 \%)$ pedig az első 6 hónapon belül született meg a malignus daganat diagnózisa [8].

Amerikában egy daganatos betegeket bevonó, 2005 és 2013 között végzett vizsgálatban a tumor felismerését megelőző periódust elemezték. Azt találták, hogy a 67 éves vagy idősebb 374331 , tumoros betegben a daganat diagnózisát megelőző 150 nap során szignifikánsan gyakoribb volt az artériás thrombosis (a szívinfarktus és az ischaemiás stroke) előfordulása [9]. A rák diagnózisa elótti 30 nap során $2313(0,62 \%)$ betegnél jelentkezett 
artériás thrombosis, míg a demográfiai tényezőkre és a társbetegségekre illesztett tumormentes kontrollcsoportban 413-nál (0,11\%) (OR: 5,63, 95\% CI: 5,076,25) [9]. A tendenciák hasonlóak a szívinfarktus és az ischaemiás stroke tekintetében: a malignus daganat felismerését megelőző 30 napban a szívinfarktus és a stroke esélyhányadosa az illesztett kontrollcsoporthoz hasonlítva 6,43 (95\% CI: 5,57-7,41), illetve 5,04 (95\% CI: 4,3$5,88)[9]$.

A fenti eredmények alapján felmerülhet a kérdés, hogy a stroke után diagnosztizált daganatos betegekben jelen volt-e a daganat már a stroke jelentkezésekor. Ha már jelen volt, akkor a stroke történhetett-e a daganat által okozott hiperkoaguláció miatt? Feltételezhető, de nem jelenthető ki egyértelmúen, hogy minél rövidebb idő telt el a stroke és a daganat diagnózisa között, annál nagyobb a valószínúsége, hogy a daganat már jelen volt a stroke kialakulásakor. A stroke után diagnosztizált daganatok felismerésének idejére irányuló vizsgálatokat a 2. táblázat foglalja össze $[6,8,9]$.

\section{Kezelési eljárások malignus daganattal társuló stroke-ban}

\section{Antithromboticus gyógyszerek}

Az antithromboticus gyógyszerek közé a thrombocytagátlókat és a véralvadásgátlókat soroljuk, ezeket a stroke elsődleges vagy másodlagos prevenciójára rutinszerúen alkalmazzuk. Az artériás thrombosis megelőzésére elsősorban thrombocytagátlókat választunk. A leggyakrabban ciklooxigenázgátlókat (például acetilszalicilsav aszpirin) és ADP-receptor-antagonistákat (például klopidogrél) használunk.

A vénás thrombosis profilaxisára, valamint cardiogen stroke után általában véralvadásgátlókat alkalmazunk. A véralvadásgátlók három gyakran alkalmazott csoportja a heparin (kis molekulasúlyú heparin [LMWH]), a Kvitamin-antagonisták (VKA, például acenokumarol, warfarin) és újabban a direkt oralis véralvadásgátló készítmények (DOAC-ok). Az utóbbi csoportba tartoznak az

2. táblázat |A stroke után felismert daganatok felismerésének idejére irányuló vizsgálatok $[6,8$, 9]

\begin{tabular}{|c|c|c|c|c|c|}
\hline $\begin{array}{l}\text { Szerző } \\
\text { és évszám }\end{array}$ & Vizsgálati csoport & Kontrollcsoport & $\begin{array}{l}\text { A vizsgált periódus } \\
\text { a stroke-hoz képest }\end{array}$ & $\begin{array}{l}\text { A daganat gyakorisága/kockázata } \\
\text { a stroke után (zárójelben a p-érték, } \\
\text { illetve a } 95 \% \mathrm{CI})\end{array}$ & Megjegyzés \\
\hline $\begin{array}{l}\text { Selvik, } \\
2015 \text { [8] }\end{array}$ & $\begin{array}{l}\text { A Norvég Stroke } \\
\text { Regiszter } 2006 \text { és } \\
2011 \text { közötti } \\
\text { betegei, stroke után } \\
\text { felismert daganattal } \\
(n=55)\end{array}$ & $\begin{array}{l}\text { A Norvég Stroke } \\
\text { Regiszter betegei, } \\
\text { stroke után nem } \\
\text { alakult ki daganat } \\
(\mathrm{n}=1227)\end{array}$ & A stroke utáni 2 év & $\begin{array}{l}\text { A tumor felismerésének ideje } \\
\text { a stroke után: } \\
\text { - } 1 \text { hónapon belül } 4 / 55 \\
\text { - } 3 \text { hónapon belül } 9 / 55 \\
\text { - } 6 \text { hónapon belül } 13 / 55 \\
\text { - } 12 \text { hónapon belül } 23 / 55\end{array}$ & $\begin{array}{l}\text { Kis esetszám, rövid követési } \\
\text { idő (medián: } 27 \text { hónap, } \\
\text { IQR: 14-42 hónap) }\end{array}$ \\
\hline $\begin{array}{l}\text { Jacob, } \\
2019[6]\end{array}$ & $\begin{array}{l}2006 \text { és } 2015 \\
\text { között, németországi } \\
\text { háziorvosi praxisok, } \\
\text { tumormentes } \\
\text { stroke-betegek } \\
(\mathrm{n}=18688)\end{array}$ & $\begin{array}{l}\text { Illesztett tumor- } \\
\text { és stroke-mentes } \\
\text { kontrollcsoport } \\
(\mathrm{n}=18688)\end{array}$ & $\begin{array}{l}\text { (1) A stroke utáni } \\
1 \text { éven belül } \\
\text { (2) A stroke utáni } \\
1 \text { éven túl } 10 \text { éven } \\
\text { át }\end{array}$ & $\begin{array}{l}\text { (1) A felismert daganat } \\
\text { gyakorisága } 1 \text { éves követésnél: } \\
\text { férfiakban: } 3,1 \% \text { vs. } 2,6 \% \\
(\mathrm{p}=0,273) \\
\text { nókben: } 2,6 \% \text { vs. } 2,1 \%(\mathrm{p}=0,092) \\
\text { (2) A felismert daganat } \\
\text { gyakorisága } 10 \text { éves követésnél: } \\
\text { férfiakban: } 29,3 \% \text { vs. } 23,8 \% \\
\text { ( } \mathrm{p}<0,001) \\
\text { nókben: } 25,0 \% \text { vs. } 20,5 \% \\
\text { (p<0,001) } \\
\text { A tumorok megjelenésének relatív } \\
\text { kockázata } 10 \text { éves követésnél: } \\
\text { férfiaknál: } 1,18(1,09-1,28) \\
\text { nóknél: } 1,22 \text { (1,12-1,34) }\end{array}$ & $\begin{array}{l}\text { Számottevő kockázatnöveke- } \\
\text { dés a következő tumortípu- } \\
\text { sok megjelenésére: } \\
\text { Férfiakban: } \\
\text { szem és idegrendszer: } \\
2,35(0,98-5,67) \\
\text { ajak, szájüreg és garat: } \\
1,76(0,96-3,25) \\
\text { emésztőrendszeri: } \\
1,44(1,18-1,76)^{*} \\
\text { légzőrendszeri és intrathora- } \\
\text { calis: } 1,36(1,0-1,81)^{*} \\
\text { bőr: } 1,22(0,99-1,50) \\
\text { Nőkben: } \\
\text { szem és idegrendszer: } \\
2,75(0,87-8,62) \\
\text { légzőszervi és intrathoracalis: } \\
2,95(1,75-4,95)^{*}\end{array}$ \\
\hline $\begin{array}{l}\text { Navi, } \\
2019 \text { [9] }\end{array}$ & $\begin{array}{l}\text { Az amerikai } \\
\text { Medicare-rendszer- } \\
\text { ben } 2005 \text { és } 2013 \\
\text { között megjelent, } \\
67 \text { éves vagy idösebb } \\
\text { daganatos beteg } \\
(\mathrm{n}=374331)\end{array}$ & $\begin{array}{l}\text { Azonos számú, } \\
\text { betegenként } \\
\text { illesztett daganat- } \\
\text { mentes személyek } \\
(\mathrm{n}=374331)\end{array}$ & $\begin{array}{l}\text { A daganat } \\
\text { felismerése elötti } \\
360 \text { nap, } 30 \text { napos } \\
\text { periódusokban }\end{array}$ & $\begin{array}{l}\text { Az ischaemiás stroke kockázata a } \\
\text { daganat felismerése elótti } \\
\text { - 1. hónapban: } 5,04(4,32-5,88) \\
\text { 2. hónapban: } 1,81(1,50-2,18) \\
\text { - 3. hónapban: } 1,51(1,23-1,85) \\
\text { - A teljes } 360 \text { napos időszakban: } \\
\text { 1,59 }(1,50-1,69)\end{array}$ & $\begin{array}{l}\text { A daganat diagnózisát } \\
\text { megelőző } 360 \text { nap alatt a } \\
\text { stroke előfordulása } 0,78 \% \text {, } \\
\text { míg a daganatmentes } \\
\text { csoportban } 0,49 \% \text {. } \\
\text { Nem volt különbség } \\
\text { a daganat felismerését } \\
\text { megelőző } 150 \text { nap elötti } \\
\text { időszakban. }\end{array}$ \\
\hline
\end{tabular}

$\mathrm{CI}=95 \%$-os megbízhatósági tartomány; IQR = interkvartilis tartomány; * $\mathrm{p}<0,05$ 
3. táblázat | Javaslatok az ischaemiás stroke kezelésére malignus daganatos betegekben a jelenlegi irányelvek alapján [10-17]

\begin{tabular}{lll}
\hline A kezelés célja & A jelenleg javasolt eljárás & A jövő feladatai \\
\hline Elsődleges stroke-prevenció & $\begin{array}{l}\text { Nincs tumoros betegek számára specifikusan vagy } \\
\text { általánosan javasolt gyógyszer vagy eljárás. Ha nincs }\end{array}$ & $\begin{array}{l}\text { A primer stroke-prevenció gzükségességének } \\
\text { ellenjavallat, akkor a szokásos elsődleges prevenciós } \\
\text { daganattípusonként }\end{array}$ \\
& eljárások alkalmazhatók & \\
\hline
\end{tabular}

Akut ischaemiás stroke ellátása

Intravénás thrombolysis (tPA): a 2019-es amerikai
ajánlás [13] akkor javasolja, ha (1) fél évnél hosszabb
a várható túlélés, (2) a betegnek nincs véralvadási
rendellenessége, és (3) a közelmúltban nem volt
mútéte vagy vérzése
Mechanikus thrombectomia: esetsorozatokban nem volt
nagyobb rövid távú kockázat, mint a daganatmentes
betegeknél [10-12]. Kevés az adat, nincs egyértelmú
irányelvi ajánlás

Másodlagos prevenció artériás
vérkeringési zavar által okozott stroke
után

Tumorhoz társuló fokozott véralvadékonyságot

Nagy esetsorozatok elemzése,

kontrollált vizsgálatok elvégzése

Tumorhoz társuló fokozott véralvadékonyságot

További kutatások DOAC-okkal

elsősorban LMWH [14

(például Enchase Trial [15])

Akut agyi vénás vérkeringési zavar

(sinusthrombosis)

Akut kezelés: 2011-es AHA/ASA és 2017-es európai ajánlás: heparin, LMWH, VKA [16, 17]

Hosszú távú kezelés: 2011-es AHA/ASA: VKA [16]
Kutatások folytatása DOAC-okkal Specifikus teendők meghatározása malignus tumorokhoz társuló esetekre

Az antikoaguláns kezelés időtartamának meghatározása

AHA/ASA = Amerikai Szívgyógyász Szövetség/Amerikai Stroke Egyesület; DOAC $=$ direkt oralis véralvadásgátló készítmény; LMWH $=$ kis molekulasúlyú heparin; tPA = szöveti plazminogénaktivátor; VKA = K-vitamin-antagonista

aktivált X. faktor gátlói (rivaroxabán, apixabán, edoxabán) és egy direkt trombingátló (dabigatrán). Mindhárom gyógyszercsoport hatékony, de mindegyiknek van mellékhatása is, és alkalmazásuk során óvatosság szükséges az életveszélyes vérzések veszélye miatt. A gyógyszerválasztás során három fontos szempontot veszünk figyelembe: (1) egyszerű-e az alkalmazása? (2) Ha mütétre kerül sor, egyszerü-e a hatását felfüggeszteni, majd a gyógyszeres kezelést újrakezdeni? (3) Mi az életveszélyes vérzés bekövetkeztének kockázata?

A malignus daganatokhoz társuló stroke kezelésére vonatkozó ajánlásokat a 3. táblázat foglalja össze [1017].

\section{A stroke megelözése és az akut stroke ellátása daganatos betegekben}

\section{Elsödleges stroke-prevenció daganatos betegekben}

Daganatos betegekben nincs külön ajánlás az irányelvekben a stroke elsődleges prevenciójára, ezért a mindennapi gyakorlatban - ha nincs más indikáció - nem adunk ilyen céllal gyógyszert az újonnan diagnosztizált daganatos betegeknek.

\section{Akut stroke ellátása: thrombolysis és mechanikus thrombectomia daganatos betegekben}

Akut stroke esetén daganatmentes betegekben a thrombolysis az irányelvek által javasolt, rutinszerüen alkalmazott, hatékony és biztonságos eljárás. A szöveti plaz- minogénaktivátorral (tPA) végzett thrombolysis alkalmazása malignus daganatokban szenvedő betegekben azonban nem egyértelmú, különös tekintettel a lehetséges fokozott vérzésveszélyre.

Egy koreai vizsgálatban 12, daganatos beteg akut stroke miatti kezelésére alkalmaztak thrombolysis céljából tPA-t, amely után 4 betegnél mérséklődtek a neurológiai tünetek, 7-nél vérzéses transzformáció jelentkezett, 7-nek súlyosbodott az állapota (a stroke után 3 hónappal a módosított Rankin-skála pontszáma [mRS] 3 és 5 között volt), és 3 beteg elhunyt a kórházban [18]. Egy másik vizsgálatban akut stroke miatt IV tPA-val végzett 266 thrombolysis során az 5 daganatos betegnél nem jelentkezett mellékhatás, míg a 261 daganatmentes stroke-beteg közül 10-nél figyeltek meg mellékhatást [19]. Egy 2000 és 2020 közötti periódust elemző összefoglaló áttekintés [20] a következő megállapításokra jutott: (1) axialis intracranialis tumorban az intravénás thrombolysis (IVT) alkalmazására nincsenek határozott ajánlások: minden betegnél egyedi döntés szükséges. Extraaxialis intracranialis tumorokban az IVT alkalmazása biztonságosnak tûnik. (2) Emésztőszervi daganatokban megfontolandó az IVT, mivel gyakrabban véreznek. Ezért a tPA alkalmazása előtt figyelembe kell venni a metastasist okozó daganat típusát. (3) Nincs elég adat hematológiai daganatokban arra, hogy milyen határértékü thrombocytopenia esetén ne kapjon a beteg tPA-t, de 20 G/l alatt a tPA biztosan nem alkalmazható. (4) A cardialis myxoma korábban a tPA-kezelés ellenjavallataként szerepelt, de 3 kisebb vizsgálatban szövődménymentesen alkalmaztak tPA-t ilyen esetben. 
A mechanikus thrombectomia vonatkozásában Koreából és Olaszországból közöltek kisebb esetsorozatokat. Lee és mtsai 2014 és 2020 között végzett 341 beavatkozást elemeztek: a betegek közül 34 volt daganatos (kizárták a hematológiai és a központi idegrendszeri daganatokat), és nem találtak statisztikai különbséget a thrombectomia akut eredményességében [21]. A 34, daganatos betegben a daganat nélküli kontrollcsoporthoz képest gyakoribb volt a vérzéses szövődmény a thrombectomia után (41,2\%, míg a kontrollban 23,8\%, $\mathrm{p}=0,037$ ), és a késői funkcionális állapot is rosszabb volt [21]. A 34, daganatos betegból 3 hónappal a thrombectomia után 23-nál volt kedvezőtlen a kimenetel $(\mathrm{mRS} \geq 3)$. Ezen betegeknél a kedvező kimenetelú 11 beteghez képest a D-dimer-szint jelentősen magasabb volt (medián 16,9 vs. 10,7), a stroke a kórházi felvételi NIHSS-pontszám alapján súlyosabb volt (medián NIHSS-pontszám 20 vs. 9), és gyakoribb volt a hasnyálmirigytumor [21].

Jung és mtsai 2011 és 2015 között kezelt 329 beteg adatainak retrospektív elemzése során a tumorhoz társuló 19 esetben a thrombectomiát követő sikeres rekanalizáció arányát 64\%-nak találták a nagyéreredetű és a cardioemboliás mechanizmussal kialakuló stroke-okban elért 84\%-kal szemben, de a klinikai eredményességben nem volt különbség [10]. Yoo és mtsai 1338 beteg adatait elemezték, közülük 62-nek aktív, 78-nak nem aktív daganata volt. Mechanikus thrombectomia 685 esetben történt, 316 esetben intravénás thrombolysissel együtt. Aktív malignus tumor fennállása mellett a mellékhatások és a rövid távú klinikai eredményesség hasonló volt, mint a nem aktív daganatos és a daganatmentes csoportokban [11]. Ciolli és mtsai 2008 és 2016 között végzett 281, mechanikus thrombectomiás beavatkozás kimenetelét vizsgálták 14 tumoros és 267 daganatmentes betegnél. A sikeres reperfúzió aránya $71 \%$, illetve $78 \%$ volt. Cryptogen stroke-osnak 4 daganatos és 50 daganatmentes beteget tartottak, közöttük a reperfúzió 2, illetve 37 esetben $(50 \%$, illetve $74 \%)$ volt sikeres [12].

Összességében tehát elmondható, hogy még nem vizsgálták kellően nagy számú daganatos akut stroke-os betegben sem az intravénás thrombolysis, sem a mechanikus thrombectomia következményeit, ezért az irányelvek óvatosan fogalmaznak. Az American Heart Association/American Stroke Association (AHA/ASA) 2019. évi ajánlása is hangsúlyozza, hogy kevés a rendelkezésre álló adat a thrombolysis daganatos betegekben történő alkalmazásáról [13]. A tPA-kezelést akkor javasolják, ha (1) fél évnél hosszabb a várható túlélés, (2) a betegnek nincs véralvadási rendellenessége, és (3) a közelmúltban nem volt mütéte vagy vérzése [13]. Fontos tudni, hogy vannak fokozott vérzésveszéllyel járó daganattípusok, mint a gastrointestinalis daganatok, különösen azokban a betegekben, akikben vérzés jelentkezett a megelőző 3 hét során [13]. Végleges következtetést a kis esetszámok miatt jelenleg még a malignus tumorban szenvedő akut stroke-os betegekben történő thrombectomiára vonatkozóan sem vonhatunk le. Több beteget bevonó vizsgá- latokra van szükség ahhoz, hogy megállapíthassuk, mi az akut stroke legbiztonságosabb kezelése daganatos betegekben.

\section{Másodlagos prevenció daganatos betegekben jelentkező agyi artériás vérkeringési zavar után}

A daganatos betegekben a stroke leggyakrabban a daganat felismerését követő első évben jelenik meg [22], és a fordítottja is igaz: a stroke után felismert daganatokat a leggyakrabban a stroke utáni első évben diagnosztizálják. Ez a szoros időbeli kapcsolat két kérdést vet fel: (1) Artériás thrombosis bekövetkezte esetén nem lehet egyértelmúen megállapítani, hogy az artériás thrombosis a stroke és a daganat átfedő rizikófaktorai miatt, vagy pedig a daganat által okozott hiperkoaguláció következtében jött létre. Ez azért fontos kérdés, mert még nem ismert, hogy ugyanolyan módon és ugyanazokat a gyógyszereket lehet-e használni stroke-prevencióra a daganat nélküli (akiknél nincs jelen daganat által okozott hiperkoaguláció) és a daganatos (feltehetően jelen lévő daganat által okozott hiperkoaguláció) betegekben. (2) Ha a stroke prezentációja egy nem ismert daganatos betegben nem tipikus, lehet, hogy a háttérben még nem felismert malignus tumor áll, és ezért a másodlagos stroke-prevencióra nem a szokásos stroke-prevencióra alkalmazott gyógyszereket kellene használni.

Az első lépés annak eldöntése, hogy a stroke hátterében nem egy specifikus daganat által okozott hiperkoagulációs környezet áll-e. Ennek a kérdésnek a megválaszolásában segíthet a D-dimer-szint és az MRI-lelet. A D-dimer-szintet óvatosan kell értelmezni, mert nem specifikus marker a daganat által okozott hiperkoagulációra, hanem például nagy méretû daganatokban is emelkedett lehet a szintje $[23,24]$. Az agyi MRI során multifokális, több ér ellátási területében kialakuló ischaemiás károsodás veti fel a malignus tumorhoz társuló hiperkoaguláció oki szerepét [23]. Ám a több érterületben jelentkező multifokális ischaemiás károsodás sem jelez feltétlenül fokozott véralvadékonyságot; a hátterében cardiogen embolisatio is állhat.

Napjainkban a malignus betegségekhez társuló strokeot követő másodlagos prevenció során - fokozott véralvadékonyságot feltételezve - gyakran alkalmaznak antikoaguláns kezelést, amely azonban malignus daganatban szenvedő betegeknél több megfontolást igényel. A VKAkezelés az 'international normalized ratio' (INR) rendszeres ellenőrzését igényli, amit rosszindulatú daganatos betegekben nem mindig könnyü megszervezni. A VKAkezelés további hátránya, hogy mütét előtt a kezelés átállítása szükséges [24]. Egy másik fontos probléma, hogy a kemoterápiás gyógyszerek egy része hatással van a K-vitamin-anyagcserére [25]. Egy retrospektív vizsgálatban a malignus kórképekhez társuló stroke ismétlődésé- 
nek megelőzésére hatékonyabb volt az LMWH, mint a VKA [14].

Az LMWH és a DOAC alkalmazásának is megvannak a problémái. Az LMWH alkalmazásának gátja a rendszeres injekciózás szükségessége, ami az adherencia fokozatos csökkenéséhez vezet: azon daganatos betegek, akiknek akut mélyvénás thrombosisuk volt, 6 hónap múlva már csak 37\%-ban alkalmaztak LMWH-t [26]. Warfarin és DOAC (rivaroxabán) mellett az adherencia 6 hónapnál 61\% volt [26]. Egy 2018-as klinikai kutatásban elemezték, hogy a daganat által okozott hiperkoagulációs állapotban a vénás thromboembolia (VTE) képződésének kivédésére jobban múködik-e az LMWH, mint egy DOAC (edoxabán) [27]. Nem találtak szignifikáns különbséget a VTE-események számában, és nem volt szignifikáns különbség az életveszélyes vérzések számában sem [27]. Sajnos még nincs elég információ arról, hogy malignus tumorban szenvedóknél a DOAC-ok mennyire gátolják a thrombosisképződést úgy, hogy közben nem okoznak veszélyes vérzést. Ezért az irányelvek jelenleg még nem javasolják a DOAC-ok alkalmazását az LMWH-k helyett malignus betegséghez társuló stroke-ot követő másodlagos prevencióra.

Jelenleg folynak olyan kontrollált vizsgálatok a malignus tumorokhoz társuló ischaemiás stroke-ok másodlagos prevenciójára, melyekben véralvadásgátlót hasonlítanak thrombocytagátlóhoz (enoxaparint aszpirinhez [28]; LMWH-t DOAC-hoz [29]), illetve malignus daganatokkal társuló ismeretlen eredetû emboliás strokeokban (ESUS) is javasolják további randomizált kontrollált klinikai vizsgálatok végzését [27]. Az Enchase Trial egy LMWH (enoxaparin) és egy DOAC (edoxabán) hatását vizsgálja daganatos betegekben bekövetkező stroke után [15]. Jelenleg folynak olyan prospektív kohorszmegfigyelések (MOST-Cancer és OASIS-Cancer), melyek malignus daganathoz társuló ESUS-ban elemzik a hiperkoagulabilitás biomarkereit és az antithromboticus kezelés egyes jellemzőit $[30,31]$. Mivel a malignus betegségekhez társuló stroke-ok patogenezisében felvetődött a neutrophil extracelluláris csapdák (neutrophil extracellular traps: NET-ek) szerepe, új feladatként kínálkozik a NET-ek hatástalanítására irányuló kezelési eljárások vizsgálata [32].

\section{Az agyi vénás és sinusthrombosis kezelése}

Malignus daganatokhoz agyi vénás keringészavar (agyi vénás és sinusthrombosis) is társulhat. Az életveszélyes vérzéstől való félelem miatt eddig a legtöbb vizsgálatban olyan betegeket kezeltek véralvadásgátlóval, akiknél már megjelent a daganat által okozott hiperkoaguláció klinikai következménye [33]. A 2016. évi CHEST-irányelv fogalmazza meg a VTE-ben szenvedő betegek véralvadásgátló kezelésének általános ajánlásait [34]. Azon daganatos betegekben, akikben VTE már bekövetkezett, LMWH-t javasolnak az oralis antikoagulánsokkal szemben, hosszú távú kezelésre is [34].
Az agyi vénás sinusthrombosis kezelése hasonló a VTE-éhez. Az egyes vizsgálatokban különböző antikoagulánsokat (heparin, LMWH, VKA és DOAC) alkalmaztak. Az AHA/ASA 2011. évi irányelve az akut fázisban heparin, LMWH vagy VKA, míg hosszú távú profilaxisra VKA alkalmazását javasolja [16]. A 2017-es európai ajánlás az akut szakaszban LMWH-kezelést javasol [17]. Legújabban esetismertetésekben a különbözó DOAC-ok kipróbálásáról számolnak be, de még kevés a tapasztalat a DOAC-ok agyi sinusthrombosisban történő alkalmazásával. Bár az 55 év fölötti korcsoportban az agyi sinusthrombosisok hátterében gyakori a malignus tumor [35], specifikusan a malignus betegségekhez társuló agyi vénás és sinusthrombosisok kezelésére nincsenek irányelvszintű ajánlások.

\section{További kérdések}

Az egyik megválaszolatlan kérdés, hogy mely daganattípusokban biztonságos és melyekben veszélyes a véralvadásgátló kezelés. Onkológiai osztályon kezelt 3358, daganatos betegról készült retrospektív vizsgálatban azt találták, hogy gastrointestinalis daganatok mellett nagyobb a súlyos, valamint a klinikailag releváns, de nem súlyos vérzés kockázata (OR: 2,96, CI: 1,96-5,18, $\mathrm{p}<0,001)$ a többi daganathoz képest [36]. A kórházi kezelést indokló vérzés prediktora volt a 40 fölötti testtömegindex, az alacsony vérlemezkeszám és az anaemia [36]. Érdekes módon alacsonyabb volt a vérzés kockázata azokban a betegekben, akik az első kórházi napon antikoaguláns gyógyszert kaptak (OR: 0,5, 95\% CI: 0,3$0,8, p=0,004)[36]$. Fontos limitáció, hogy nem tudták, melyik beteg kapott antikoaguláns kezelést már a felvétele elött otthonában, és hogy a kórházi kezelés során az antikoaguláns kezelést terápiás vagy preventív adagban adták-e [36]. További vizsgálatok szükségesek tehát annak eldöntésére, hogy mely daganattípusok mellett nagyobb az antikoaguláns kezelés során jelentkező vérzés kockázata, és hogy melyik antikoaguláns a legbiztonságosabb.

Az említett korábbi kutatásokban azt találták, hogy ismert VTE-betegség esetén gyakoribb az atherosclerosis. Azt is tudjuk, hogy a VTE daganatos betegekben gyakrabban fordul elö, mint az ischaemiás stroke. Daganatos betegekben jelentkező VTE esetén érdemes megvizsgálni, hogy van-e a betegnek atherosclerosisa is. Olyan daganatos betegekben, akiknél nem ismert a VTE oka, fontos lehet arra gondolni, hogy nagyobb lehet az ischaemiás stroke kockázata is. Ezekre a kérdésekre jelenleg még nincs válasz.

Egy másik fontos kérdés, hogy amikor a stroke a daganat diagnózisa előtt jelentkezik, mennyi időbeli különbség mellett lehet biztosan kimondani, hogy a daganat még nem létezett a betegben, és a daganat nem befolyásolta a stroke megjelenését. A korábban hivatkozott vizsgálatokban, melyekben a daganatot csak a stroke után ismerték fel, nem tudjuk, hogy jelen volt-e már a daganat 
által okozott hiperkoaguláció a stroke jelentkezésekor. Ezért feltehető, hogy a korábbi vizsgálatok alulbecsülték a malignus tumoroknak betudható stroke-esetek számát.

\section{Daganat keresése stroke-betegekben}

A mindennapos gyakorlatban az ischaemiás stroke etiológiáját a TOAST-kritériumok alapján 5 csoportba soroljuk: nagyér-atherosclerosis; agyi kisérbetegség; cardioemboliás mechanizmus; egyéb ismert ok; és nem ismert vagy nem meghatározható ok [37]. Ismeretlen eredetú stroke hátterében malignus daganat által okozott hiperkoagulációra is kell gondolni [15]. Fontos rákérdezni a fogyásra, az éjszakai izzadásra, a fáradékonyságra, a dohányzásra, a túlzott mértékű alkoholfogyasztásra. A rutin laboratóriumi leletek közül a C-reaktív fehérje és a D-dimer emelkedett szintje, valamint a CT/MR-vizsgálattal több érterületben kimutatható ischaemiás területek kelthetnek gyanút, ekkor indokolt mellkasi és hasi képalkotó vizsgálat (CT vagy MRI) elvégzése [4, 7, 15].

\section{Következtetések}

- Ismeretlen eredetú (cryptogen) ischaemiás stroke-ok hátterében állhat a daganat által okozott hiperkoaguláció is.

- Daganat által okozott hiperkoagulációhoz társulhat ischaemiás stroke, mely a malignus daganat felismerését követő első 6 hónapon belül a leggyakoribb.

- Ischaemiás stroke után a leggyakrabban 6 hónapon belül diagnosztizálnak rosszindulatú daganatot. Ismeretlen etiológiájú stroke esetén minél rövidebb idő telik el a stroke után a daganat felismeréséig, annál valószínúbb, hogy az ischaemiás stroke az első jele volt egy már meglévő daganatnak.

- A tüdő-, az emlőcarcinoma és a melanoma a leggyakoribb daganattípusok, melyekben ischaemiás stroke jelentkezik.

- Daganatos betegekben elsődleges stroke- vagy VTEprevencióra nincs specifikus ajánlás; az általános elsődleges prevenciós teendők javasolhatók.

- Malignus betegség mellett fellépő akut stroke-ban thrombolysis és thrombectomia szóba jöhet.

- Másodlagos stroke-prevencióra malignus tumorokhoz társuló ischaemiás stroke után elsósorban LMWH javasolt, de vizsgálatok folynak egyéb antithromboticus gyógyszerekkel.

- Akut agyi vénás keringészavar (agyi vénás és sinusthrombosis) ellátására nincs specifikusan a malignus tumorok esetére javasolt ajánlás, a sinusthrombosisokra vonatkozó általános ajánlások követése indokolt.

Anyagi támogatás: A kutatás a Fulbright-ösztöndíj támogatásával valósult meg.
Szerzői munkamegosztás: H. N.: A koncepció, irodalomkutatás, a kézirat megfogalmazása és végleges formába hozása. B. D.: A koncepció, a kézirat egymást követő verzióinak kritikus véleményezése. A cikk végleges változatát mindkét szerző elolvasta és jóváhagyta.

Érdekeltségek: A szerzőknek nincsenek érdekeltségeik.

\section{Irodalom}

[1] Hajnóczky N, Bereczki D. The relationship between malignant tumors and ischemic stroke. I. Thrombosis development and shared risk factors. [A malignus daganatok és az ischaemiás stroke kapcsolata - I. A thrombosis kialakulása, átfedo" kockázati tényezők.] Orv Hetil. 2022; 163: 3-11. [Hungarian]

[2] Zöller B, Ji J, Sundquist J, et al. Risk of haemorrhagic and ischaemic stroke in patients with cancer: a nationwide follow-up study from Sweden. Eur J Cancer 2012; 48: 1875-1883.

[3] Navi BB, Reiner AS, Kamel H, et al. Risk of arterial thromboembolism in patients with cancer. J Am Coll Cardiol. 2017; 70: 926-938.

[4] Uemura J, Kimura K, Sibazaki K, et al. Acute stroke patients have occult malignancy more often than expected. Eur Neurol. 2010; 64: 140-144.

[5] Cocho D, Gendre J, Boltes A, et al. Predictors of occult cancer in acute ischemic stroke patients. J Stroke Cerebrovasc Dis. 2015; 24: 1324-1328.

[6] Jacob L, Kostev K. Cancer risk in stroke survivors followed for up to 10 years in general practices in Germany. J Cancer Res Clin Oncol. 2019; 145: 1013-1020.

[7] Kreisl TN, Toothaker T, Karimi S, et al. Ischemic stroke in patients with primary brain tumors. Neurology 2008; 70: 23142320.

[8] Selvik HA, Thomassen L, Bjerkreim AT, et al. Cancer-associated stroke: the Bergen NORSTROKE study. Cerebrovasc Dis Extra 2015; 5: 107-113

[9] Navi BB, Reiner AS, Kamel H, et al. Arterial thromboembolic events preceding the diagnosis of cancer in older persons. Blood 2019; 133: 781-789.

[10] Jung S, Jung C, Hyoung Kim J, et al. Procedural and clinical outcomes of endovascular recanalization therapy in patients with cancer-related stroke. Interv Neuroradiol. 2018; 24: 520-528.

[11] Yoo J, Kim YD, Park H, et al. Immediate and long-term outcomes of reperfusion therapy in patients with cancer. Stroke 2021; 52: 2026-2034.

[12] Ciolli L, Bigliardia G, Ferraro D, et al. Efficacy of mechanical thrombectomy in patients with ischemic stroke and cancer. J Clin Neurosci. 2021; 91: 20-22.

[13] Powers WJ, Rabinstein AA, Ackerson T, et al. Guidelines for the early management of patients with acute ischemic stroke: 2019 update to the 2018 guidelines for the early management of acute ischemic stroke: a guideline for healthcare professionals from the American Heart Association/American Stroke Association. Stroke 2019; 50: e344-e418.

[14] Jang H, Lee JJ, Lee MJ, et al. Comparison of enoxaparin and warfarin for secondary prevention of cancer-associated stroke. J Oncol. 2015; 2015: 502089.

[15] Bang OY, Chung JW, Lee MJ, et al. Cancer-related stroke: an emerging subtype of ischemic stroke with unique pathomechanisms. J Stroke 2020; 22: 1-10.

[16] Saposnik G, Barinagarrementeria F, Brown RD Jr, et al. Diagnosis and management of cerebral venous thrombosis: a statement for healthcare professionals from the American Heart Association/American Stroke Association. Stroke 2011; 42: 11581192 . 
[17] Ferro JM, Bousser MG, Canhão P, et al. European Stroke Organization guideline for the diagnosis and treatment of cerebral venous thrombosis - endorsed by the European Academy of Neurology. Eur J Neurol. 2017; 24: 1203-1213.

[18] Nam KW, Kim CK, Kim TJ, et al. Intravenous thrombolysis in acute ischemic stroke with active cancer. Biomed Res Int. 2017; 2017: 4635829

[19] Selvik HA, Naess H, Kvistad CE. Intravenous thrombolysis in ischemic stroke patients with active cancer. Front Neurol. 2018; 9: 811 .

[20] Ladak AA, Sandhu S, Itrat A. Use of intravenous thrombolysis in acute ischemic stroke management in patients with active malignancies: a topical review. J Stroke Cerebrovasc Dis. 2021; 30: 105728 .

[21] Lee EJ, Bae J, Jeong HB, et al. Effectiveness of mechanical thrombectomy in cancer-related stroke and associated factors with unfavorable outcome. BMC Neurol. 2021; 21: 57.

[22] Wei YC, Chen KF, Wu CL, et al. Stroke rate increases around the time of cancer diagnosis. Front Neurol. 2019; 10: 579.

[23] Kim SG, Hong JM, Kim HY, et al. Ischemic stroke in cancer patients with and without conventional mechanisms: a multicenter study in Korea. Stroke 2010; 41: 798-801.

[24] Schwarzbach CJ, Schaefer A, Ebert A, et al. Stroke and cancer: the importance of cancer-associated hypercoagulation as a possible stroke etiology. Stroke 2012; 43: 3029-3034.

[25] Lee YJ, Park JK, Uhm JS, et al. Bleeding risk and major adverse events in patients with cancer on oral anticoagulation therapy. Int J Cardiol. 2016; 203: 372-378.

[26] Khorana AA, McCrae KR, Milentijevic D, et al. Current practice patterns and patient persistence with anticoagulant treatments for cancer-associated thrombosis. Res Pract Thromb Haemost. 2017; 1: 14-22

[27] Raskob GE, van Es N, Verhamme P, et al. Edoxaban for the treatment of cancer-associated venous thromboembolism. N Engl J Med. 2018; 378: 615-624.
[28] Navi BB, Marshall RS, Bobrow D, et al. Enoxaparin vs aspirin in patients with cancer and ischemic stroke: the TEACH pilot randomized clinical trial. JAMA Neurol. 2018; 75: 379-381.

[29] Nam KW, Kim CK, Kim TJ, et al. Treatment of cryptogenic stroke with active cancer with a new oral anticoagulant. J Stroke Cerebrovasc Dis. 2017; 26: 2976-2980.

[30] Navi BB, Kasner SE, Elkind MS, et al. Cancer and embolic stroke of undetermined source. Stroke 2021; 52: 1121-1130.

[31] Bang OY, Chung JW, Cho YH, et al. Circulating DNAs, a marker of neutrophil extracellular traposis and cancer-related stroke: the OASIS-cancer study. Stroke 2019; 50: 2944-2947.

[32] Chen C, Huang T, Zhai X, et al. Targeting neutrophils as a novel therapeutic strategy after stroke. J Cereb Blood Flow Metab. 2021; 41: 2150-2161.

[33] Hsu JY, Liu AB. Anticoagulants for cancer-associated ischemic stroke. Ci Ji Yi Xue Za Zhi. 2019; 31: 144-148.

[34] Kearon C, Akl EA, Ornelas J, et al. Antithrombotic therapy for VTE disease: CHEST guideline and expert panel report. Chest 2016; 149: 315-352.

[35] Ulivi L, Squitieri M, Cohen H, et al. Cerebral venous thrombosis: a practical guide. Pract Neurol. 2020; 20: 356-367.

[36] Patell R, Gutierrez A, Rybicki L, et al. Identifying predictors for bleeding in hospitalized cancer patients: a cohort study. Thromb Res. 2017; 158: 38-43.

[37] Adams HP Jr, Bendixen BH, Kappelle LJ, et al. Classification of subtype of acute ischemic stroke. Definitions for use in a multicenter clinical trial. TOAST. Trial of Org 10172 in acute stroke treatment. Stroke 1993; 24: 35-41.

(Bereczki Dániel dr., Budapest, Balassa u. 6., 1083 e-mail: bereczki.daniel@med.semmelweis-univ.hu)

\section{"Felicitatem in dubiis virtus impetrat." (Válságos helyzetben boldogulni az erény segít.)}

A cikk a Creative Commons Attribution 4.0 International License (https://creativecommons.org/licenses/by/4.0/) feltételei szerint publikált Open Access közlemény melynek szellemében a cikk bármilyen médiumban szabadon felhasználható, megosztható és újraközölhető, feltéve, hogy az eredeti szerző és a közlés helye illetve a CC License linkje és az esetlegesen végrehajtott módositások feltüntetésre kerülnek. (SID_1) 